debate. He said that the Colonial Office is not so academic as is often assumed; adding that he generally finds someone with first-hand and recent knowledge of any particular Colony at his immediate disposal. As regards suggestions for improvements in recruitment, they would be borne in mind; he pleaded that diriculty of war-time communication has made consultation slow and laborious. The Colonial Service consists of individuals employed under a variety of geographical conditions by a variety of Colonial Governments; European officers form only a small fraction of the whole. Hence re-organization of the Service is a matter, not for the Colonial Office alone, but for legislative bodies all over the world. Two main principles of development must be recognized; there must be partnership of the Colonial peoples in administration, but a substantial body of officers of European stock is still necessary to supplement local man-power. The formation some thirteen years ago 'of a series of unified professional services has provided a pool of highly qualified men who can be posted to any Colony and moved from one to another. Nevertheless he agreed that there should be nothing static in Colonial administration, and the whole position as regards this and other points raised is being examined in association with the Colonial Governments.

\section{Packaging Research Committee}

The Printing and Allied Trades Research Association has'set up a Packaging Research Committee to carry out investigations concerned with packages of which paper, board, film or foil form the main part. The research work will be carried out by the Association, which will set up a new department for the purpose, using its own laboratories or other research organizations as may be most appropriate. Preliminary consideration will be given to the systematic investigation of the elementary principles of the relation between the make-up of packages and their performance in use. The Association will also collect empirical data from individual firms in Great Britain and abroad with the view of obtaining a basis for long-range research. The outline programme already drawn up includes investigations on the penetration of various packaging materials by vapours, liquids, gases, heat and light, the effect of impregnation with various materials, damage by pests, design of packages, methods of sealing, and optimum use of automatic packaging machinery. Some ninety members of the industry have already applied for membership under the scheme. Communications should be addressed to the Director of Research, Printing and Allied Trades Research Association, 101 Princes Gardens, Acton, London, W.3.

\section{Race Theories}

ON February 8 a well-attended meeting of the Manchester University Branch of the Association of Scientific Workers heard a lecture on "Race Theories" by Prof. F. Wood Jones. The differences between various types of men are suncient for them to be classified in three distinct species, the leiotrichi or mongol, the ulotrichi or negro, and the cymotrichi. The last-named species, to which we belong, is rather less easy to define. Since interbreeding between the species readily occurs, the view that there is only one species, Homo sapiens, has been widely, held. Numerous zoological and botanical examples of the interbreeding of species with the production of fertile offspring are now known, and it is therefore again justifiable to speak of three distinct species, particularly as they can be distinguished in embryo less than three months old, as well as in fossil remains of the pleistocene period. Within these species are numerous sub-species or races, each with distinct characteristics. Segregation whether geographical, or religious and political as in the case of the Jews in Europe, tends to produce such races. Nevertheless in Europe at the present time there is no nation in which more than 10 per cent of the population belongs to a pure race. The belief that half-breeds of certain races inherit the worst qualities of both races is quite unfounded. The belief probably arose because in certain cases only the least desirable elements in both races produced such half-breeds. Professor Wood Jones strongly advocated intermarriage between all races.

\section{Multi-part Domestic Electrical Tariffs}

A PAPER under the title "Towards the 'Correct' Domestic Multi-Part Tariff" was read by P. Schiller before the Institution of Electrical Engineers in London on February 4. The author pointed out that the principle of multi-part costing and charging is again attaining particular importance in the intensive development of the domestic thermal load, which requires the unit charge component of multi-part tariffs to be reduced to the bare minimum. The necessary corollary of allocating to the standingcharge component the bulk of the actual standing costs involved in giving supply is impracticable with conventional two-part tariffs. At present the standing charge covers little more than the standing costs due to the demand for lighting and small domestic appliances, which is but a small fraction of the total demand of modern domestic installations. Hence the bulk of the standing costs due to the domestic thermal load must be averaged out on the unit-charge component.

A 'correct' domestic multi-part tariff must take account of the individual consumer's demand, and this becomes more and more justifiable as interconsumer diversity grows poorer in consequence of the predominance of the space-heating load. Owing to the rigid character of lighting and cooking demands, it appears to be sulficient to consider the individual consumer's demand only in connexion with the elastic requirements of water-heating and spaceheating. Tariff charges based on actual demand can be put into effect by either recording or limiting consumers' maximum demands during periods of heavy load on the general supply system. As to the second alternative, the 'contract-demand' method can be developed to such an extent as to be capable of everything the maximum demand indicator method achieves, while obviating the drawbacks of the latter. Thus a 'correct' domestic multi-part tariff may be found in a revival and modernization of the contract-demand method. Whether such a tariff is also an ideal one is open to discussion. But the principle of charging domestic supplies on the basis of both consumption and demand is worth reconsidering at all events.

\section{Boiler-House Measurements and Control}

A PAPER by G. H. Barker and A. L. Hancock, read before the Institution of Electrical Engineers in London recently, on boiler-house measurements with special reference to the efficient utilization of fuel, reviews the development of boiler-plant instrumenta- 